\title{
Research on accounting assessment method of thermal power enterprises based on low carbon economy
}

\author{
Xiang-song Meng \\ Department of Economic Management, North China Electric Power University,Baoding, China
}

\begin{abstract}
China is one of the countries with highest carbon emission in the world, and we must endeavor to change our traditional development model to low carbonization one Combined with the production conditions, this paper selects quantitative and qualitative indexes of low carbon which are adaptive to the actual situation of thermal power enterprises in China. Principle component analysis is adopted to construct the model of quantitative indexes of low carbon and analysis hierarchy process is used to determine the weight of qualitative indexes of low carbon, finally, the article take HuaNeng Power International INC for example to carry out an application test for the constructed model.
\end{abstract}

Keywords: Low carbon economy; Accounting assessment; Thermal power enterprise

\section{Introduction}

With global warming, air quality deterioration and a series of environmental problems worsening, low carbon economy as a new mode of economic development are more and more promoted in every country. China is the world's largest developing country, is also one of the world's largest carbon emitter. In order to realize the sustainable development and reduce greenhouse gas emissions, developing low-carbon economy and realizing the harmonious development of economy and ecological environment have become a especially important task in the process of our country's development.

At present, there is no strict regulation of enterprise environmental information disclosure requirements in Chinese Accounting Standard for Business Enterprises. Enterprise low carbon information is not included in the evaluation content in traditional accounting evaluation method. To some extent, it hindered the development of low carbon economy in enterprise process. Compared with the improved system of environmental information disclosure and foreign accounting evaluation method and system, the traditional accounting evaluation system in our country have been unable to satisfy the enterprise low carbon emissions and other environmental information disclosure requirements. Clearing corporate carbon emissions responsibility, improving the low carbon accounting information disclosure and establishing new accounting evaluation method to adapt to a low-carbon economy are important tasks of China's accounting development.

\section{Research on accounting evaluation method model based on low carbon economy}

\subsection{Principles of accounting evaluation index system build}

The principles of building accounting evaluation index system are as followed.

(1)Overall principle. Low carbon economy accounting evaluation method not only requires evaluation of enterprise production and business operation related information, including the enterprise's financial position, operating results and cash flow, but also evaluates the effect of enterprise production and operation have on the external environment, especially the impact of carbon emissions.

(2)Combine financial indicators with non-financial indicators principle. Traditional accounting evaluation methods analyze enterprise operation situation by financial index analysis and evaluation. Low carbon economy accounting evaluation method need evaluate the environmental information related to carbon emissions enterprise and this information can't simply rely on financial index to reflect.

(3)Operative principle. Evaluation indexes must be clear, concise and easy to operate. According to the current technical level and the overall quality of accounting personnel, it is difficult to achieve accurate measurement and evaluation of enterprise low carbon information. Therefore, choosing accounting evaluation method index based on low carbon economy should pay attention to the difficulty of the data acquisition and a wide range of representative.

(4)3R principle and sustainable development principle. The primary goal of the low carbon economy development is reducing carbon dioxide emissions to slow global warming. Therefore, When choosing accounting evaluation method index based on the low carbon economy, 3R principle (Reducing, process, Reusing) and sustainable development principle should be highlighted.

(5) Comparability principle. The selected accounting evaluation indicators based on low carbon economy should have stability and be higher comparable. Therefore, it should ensure an enterprise information is comparable in different periods and must strive to achieve the assessment between different enterprises is comparable also. 


\subsection{Build the evaluation index system}

Low carbon economy requires reflect the impact of characteristics of low carbon emissions information have on the traditional accounting method. Combining with the characteristics and the actual situation of thermal power enterprises in China, this paper builds enterprise low carbon performance indicators system, as shown in table 1 .

Table1 Enterprise low carbon performance index system

\begin{tabular}{|c|c|c|}
\hline \multirow{14}{*}{$\begin{array}{l}\text { Enterpris } \\
\text { e low } \\
\text { carbon } \\
\text { performa } \\
\text { nce } \\
\text { index } \\
\text { system }\end{array}$} & & Index name \\
\hline & \multirow{6}{*}{$\begin{array}{l}\text { Low } \\
\text { carbon } \\
\text { quantitati } \\
\text { ve index }\end{array}$} & $\begin{array}{c}\text { A } 1 \text { : Coal consumption quantity per } \\
\text { unit revenue } \\
\left(10^{4} \text { ton/ Hundred million }\right)\end{array}$ \\
\hline & & $\begin{array}{c}\text { B 1:Production water consumption } \\
\text { unit revenue } \\
\left(10^{4} \text { ton/Hundred million }\right)\end{array}$ \\
\hline & & $\begin{array}{c}\text { C1: Average power supply coal } \\
\text { consumption }(\mathrm{g} / \mathrm{KWH})\end{array}$ \\
\hline & & $\begin{array}{l}\text { D1: Average sulfur dioxide } \\
\text { performance value (g/ KWH) }\end{array}$ \\
\hline & & $\begin{array}{l}\text { E1:Average nitrogen oxides } \\
\text { performance value }(\mathrm{g} / \mathrm{KWH})\end{array}$ \\
\hline & & $\begin{array}{l}\text { F1:Pollution discharge fee } \\
\text { (Hundred million) }\end{array}$ \\
\hline & \multirow{7}{*}{$\begin{array}{l}\text { Low } \\
\text { carbon } \\
\text { qualitativ } \\
\text { e index }\end{array}$} & $\begin{array}{c}\text { A2: Low carbon reduction goal } \\
\text { programming }\end{array}$ \\
\hline & & $\begin{array}{c}\text { B2:importance of low carbon } \\
\text { emissions }\end{array}$ \\
\hline & & $\begin{array}{c}\text { C2: Low carbon emissions } \\
\text { industry level }\end{array}$ \\
\hline & & $\begin{array}{c}\text { D2: employee's low carbon } \\
\text { consciousness and comprehensive } \\
\text { quality }\end{array}$ \\
\hline & & E2: Low carbon reduction device \\
\hline & & $\begin{aligned} \text { F2: } & \text { Low carbon technology } \\
& \text { innovation ability }\end{aligned}$ \\
\hline & & $\begin{array}{c}\text { G2: Low carbon contribution to } \\
\text { society }\end{array}$ \\
\hline
\end{tabular}

According to table 1, the enterprise low carbon evaluation model indexes consist of low carbon quantitative indicators and qualitative indicators. In the whole analysis process, this paper mainly adopts principal component analysis (PCA) and builds low-carbon quantitative index evaluation model for low carbon quantitative indicators; and it uses analytic hierarchy process (AHP) to determine the weight of each index and determines final evaluation results through Analytic Hierarchy Process (AHP) and the expert scoring method in the actual application for low carbon qualitative indicators.

\subsection{Build accounting evaluation model}

(1)Evaluation model of low carbon quantitative index

This paper selects data of HuaNeng Power International INC from 2011 to 2013. Raw data can be obtained by consulting the company's financial report and social responsibility information, after preliminary arrangement and calculation, as shown in table 2 .
Table2 Low carbon quantitative index raw data

\begin{tabular}{|c|c|c|c|}
\hline Index name & 2011 & 2012 & 2013 \\
\hline $\begin{array}{c}\text { Coal consumption quantity per } \\
\text { unit revenue } \\
\left(10^{4} \text { ton/ Hundred million) }\right.\end{array}$ & 10.86 & 10.8 & 9.91 \\
\hline $\begin{array}{c}\text { Production water consumption } \\
\text { unit revenue } \\
\left(10^{4} \text { ton/Hundred million) }\right.\end{array}$ & 26.64 & 20.89 & 20.43 \\
\hline $\begin{array}{c}\text { Average power supply coal } \\
\text { consumption (g/ KWH) }\end{array}$ & 315.59 & 312.1 & 310.71 \\
\hline $\begin{array}{c}\text { Average sulfur dioxide } \\
\text { performance value (g/ KWH) }\end{array}$ & 0.73 & 0.57 & 0.55 \\
\hline $\begin{array}{c}\text { Average nitrogen oxides } \\
\text { performance value (g/ KWH) }\end{array}$ & 1.68 & 1.55 & 1.42 \\
\hline $\begin{array}{c}\text { Pollution discharge fee (Hundred } \\
\text { million) }\end{array}$ & 4.65 & 5.2 & 4.7 \\
\hline
\end{tabular}

Principal component analysis is carried out on the data by SPSS software. The indexes' initial characteristic value and variance can be obtained and it extracts two principal components which is $\mathrm{X} 1$ and $\mathrm{X} 2$ that replace the original evaluation indexes. The variance contribution rates of them are $75.71 \%$ and $24.29 \%$, as shown in table 3 .

Table 3 Total variance explained

\begin{tabular}{|c|c|c|c|}
\hline \multirow{2}{*}{ Component } & \multicolumn{3}{|c|}{ Initial Eigonvalues } \\
\cline { 2 - 4 } & Total & $\begin{array}{c}\text { \% of } \\
\text { Variance }\end{array}$ & Cumulative \% \\
\hline 1 & 4.5428816 & 75.714692 & 75.71469 \\
\hline 2 & 1.4571185 & 24.285308 & 100 \\
\hline 3 & $3.97 \mathrm{E}-16$ & $6.61 \mathrm{E}-15$ & 100 \\
\hline 4 & $1.10 \mathrm{E}-16$ & $1.83 \mathrm{E}-15$ & 100 \\
\hline 5 & $-2.98 \mathrm{E}-17$ & $-4.97 \mathrm{E}-16$ & 100 \\
\hline 6 & $-1.99 \mathrm{E}-16$ & $-3.32 \mathrm{E}-15$ & 100 \\
\hline
\end{tabular}

Two principal components' expressions are shown as follows.

$X 1=0.767 z 1+0.974 z 2+1.00 z 3+0.982 z 4+0.974 z 5-0.307 z 6$

$X 2=0.642 z 1-0.226 z 2-0.014 z 3-0.191 z 4+0.227 z 5+0.952 z 6 \quad$ Evaluation model of low carbon quantitative index is shown as follows by regarding the variance contribution rates of $\mathrm{X} 1, \mathrm{X} 2 \mathrm{as}$ weight.

$$
X=0.7571 X 1+0.2429 X 2
$$

(2) Evaluation model of low carbon qualitative index

This paper uses EXCEL and analytic hierarchy process (AHP) to determine the weight of the low carbon qualitative indexes, the discriminate matrix as shown in table 4 . 
Table4 Discriminate matrix of low carbon qualitative index

\begin{tabular}{|c|c|c|c|c|c|c|c|}
\hline Index & $\mathrm{A} 2$ & $\mathrm{~B} 2$ & $\mathrm{C} 2$ & $\mathrm{D} 2$ & $\mathrm{E} 2$ & $\mathrm{~F} 2$ & $\mathrm{G} 2$ \\
\hline $\mathrm{A} 2$ & 1 & 2 & $1 / 2$ & 5 & $1 / 3$ & 4 & 6 \\
\hline $\mathrm{B} 2$ & $1 / 3$ & 1 & $1 / 3$ & 4 & $1 / 4$ & 3 & 2 \\
\hline $\mathrm{C} 2$ & 2 & 3 & 1 & 4 & $1 / 2$ & 3 & 2 \\
\hline $\mathrm{D} 2$ & $1 / 5$ & $1 / 4$ & $1 / 4$ & 1 & $1 / 3$ & 3 & 2 \\
\hline $\mathrm{E} 2$ & 3 & 4 & 2 & 3 & 1 & 4 & 3 \\
\hline $\mathrm{F} 2$ & $1 / 4$ & $1 / 3$ & $1 / 3$ & $1 / 3$ & $1 / 4$ & 1 & 2 \\
\hline $\mathrm{G} 2$ & $1 / 6$ & $1 / 2$ & $1 / 2$ & $1 / 2$ & $1 / 3$ & $1 / 2$ & 1 \\
\hline
\end{tabular}

By calculation following results can be get:

The biggest characteristic root $\lambda=7.77402$

$R I=1.32, C R=C I / R I=0.09773<0.1 \quad$ Low carbon qualitative seven indexes weights are $19.68 \%, 10.97 \%$, $21.40 \%, 6.86 \%, 30.53 \%, 5.39 \%, 5.17 \%$ respectively, as shown in table 5 .

Table5 Calculation results of AHP

\begin{tabular}{|c|c|c|c|c|c|}
\hline Index & WI & AWI & AWIWI & CI & CR \\
\hline A2 & 0.196 & 1.493 & 7.591 & & \\
\hline B2 & 0.109 & 0.862 & 7.865 & & \\
\hline C2 & 0.214 & 1.628 & 7.609 & & \\
\hline D2 & 0.068 & 0.555 & 8.103 & & \\
\hline E2 & 0.305 & 2.339 & 7.662 & & \\
\hline F2 & 0.053 & 0.413 & 7.673 & & \\
\hline G2 & 0.051 & 0.409 & 7.912 & 0.129 & 0.977 \\
\hline
\end{tabular}

Evaluation model of low carbon qualitative index is shown as follows.

$$
T=\sum \alpha \times \beta
$$

$T$ :Low carbon qualitative index score

$\alpha$ :Each index weight

$\beta$ : Each index score

This paper defines a single index score full score as 100 .

(3)Accounting evaluation model based on low carbon economy

In order to build accounting evaluation model based on low carbon economy, it needs to unify Evaluation model of low carbon quantitative index and low carbon qualitative index. According to quantitative qualitative index weights allocation principles in the state-owned capital performance evaluation system, quantitative index evaluation result ac- counts for $80 \%$ of the total index evaluation results and $20 \%$ of the total index evaluation results.

Because low carbon quantitative evaluation index is negative index and low carbon qualitative evaluation index is positive index in the model, in order to eliminate evaluation direction inconsistencies of qualitative evaluation model and quantitative evaluation model it should make unified arrangement for the whole model to make the final score higher, the evaluation result more ideal. Therefore, accounting evaluation model based on low carbon economy

$$
\mathrm{P}=0.8 \times(\partial-X)+0.2 \times \sum \alpha \times \beta
$$

$P$ : Low carbon performance

$\partial$ :A constant which is bigger than $X$

$\alpha:$ Each index weight

$\beta$ : Each index score

\section{Accounting evaluation result analysis bases on low carbon economy}

According to the Evaluation model of low carbon quantitative index, low carbon performance conditions of HuaNeng Power International INC from 2011 to 2013 are researched.

Low carbon quantitative index evaluation result of HuaNeng Power International INC is shown in table6.

Table6 Low carbon quantitative index evaluation results

\begin{tabular}{|c|c|c|c|}
\hline & 2011 & 2012 & 2013 \\
\hline $\mathrm{X} 1$ & 350.79261 & 341.2035 & 338.69007 \\
\hline $\mathrm{X} 2$ & -4.6524 & 3.03644 & 2.08679 \\
\hline $\mathrm{X}$ & 264.455 & 249.0627 & 256.9291 \\
\hline $\begin{array}{c}\text { Evaluation } \\
\text { results }\end{array}$ & poor & medium & good \\
\hline
\end{tabular}


Table7 Low carbon qualitative index evaluation results

\begin{tabular}{|c|c|c|c|}
\hline Index & 2011 & 2012 & 2013 \\
\hline A2 & 83 & 80 & 86 \\
\hline B2 & 80 & 85 & 90 \\
\hline C2 & 77 & 83 & 87 \\
\hline D2 & 80 & 82 & 83 \\
\hline E2 & 75 & 85 & 90 \\
\hline F2 & 79 & 86 & 91 \\
\hline G2 & 83 & 77 & 79 \\
\hline $\begin{array}{c}\text { Evaluation } \\
\text { results }\end{array}$ & 78.5231 & 83.0225 & 87.5758 \\
\hline
\end{tabular}

Table8 Low carbon performance evaluation results

\begin{tabular}{|c|c|c|c|}
\hline Item & 2011 & 2012 & 2013 \\
\hline $\mathrm{X}$ & 264.455 & 259.0627 & 256.9291 \\
\hline $\mathrm{a}-\mathrm{X}$ & 735.545 & 740.9373 & 743.0709 \\
\hline $\begin{array}{c}\text { Low carbon } \\
\text { qualitative score }\end{array}$ & 78.5231 & 83.0225 & 87.5758 \\
\hline $\begin{array}{c}\text { Evaluation results } \\
\text { ( }\end{array}$ & 604.1406 & 609.3542 & 611.9719 \\
\hline
\end{tabular}

Low carbon qualitative indexes of HuaNeng Power International INC from 2011 to 2013 are scored by experts. The scores and evaluation results are shown in table 7.

On the basis of accounting evaluation model based on low carbon economy $\left(\mathrm{P}=0.8 \times(\partial-X)+0.2 \times \sum \alpha \times \beta\right)$, low carbon performance evaluation results of HuaNeng Power International INC can be get, which are shown in table 8 .

It can be seen that low carbon performance of HuaNeng Power International INC shows the tendency of increase year by year through the above analysis. It is consistent with the actual situation of company's attitude towards low carbon emissions and measures in recent years and it proves that the model built in this paper is reasonable.

\section{Conclusion}

With the problem of global warming brought by the growth of population and the development of economy is becoming increasingly serious, cutting down the emission of greenhouse gases and developing low carbon economy has gradually become a new economic development model among countries. Inserting low carbon information into enterprise performance evaluation is conductive to the supervision of enterprises to carry out low carbon production. Therefore, the construction of accounting assessment method built in this paper for low carbon economy is benefit to the motivation of the implementation of low carbon economy in enterprises. While accounting evaluation method based on low-carbon economy built in this paper applies only to thermal power enterprises, not all industries.

\section{References}

[1]Ratnakar Pani, Ujjaini Mukhopadhyay. Management Accounting Approach to Analyse Energy Related CO2 Emission: A Variance Analysis Study of Top 10 Emitters of the World[J]. Energy Policy, Special Section: Transition Pathways to a Low Carbon Economy,2013,52:639-655.

[2] Henrik Hammar, Magnus Sjostrom. Accounting for Behavioral Effects of Increases in the Carbon Dioxide (CO2) Tax in Revenue Estimation in Sweden[J]. Energy Policy, Sustainability of Biofuels, 2011, 39:66726676.

[3] Scott Kennedy, Sgouris Sgouridis. Rigorous Classification and Carbon Accounting Principles for Low and Zero Carbon Cities[J]. Energy Policy, 2011, 39: 5259. 5268.

[4] Henrik Hammar, Magnus Sjostrom. Accounting for Behavioral Effects of Increases in the Carbon Dioxide (CO2) Tax in Revenue Estimation in Sweden[J]. Energy Policy, Sustainability of Biofuels, 2011, 39:66726676.

[5]Mingtao Wu,Shaoping Li,Yucui Wang. Low carbon economy development mode enterprise financial evaluation research [J].Value engineering, 2012,17:5-6.

[6]Cuiying Fan,Yukun Bai. Build enterprise performance evaluation index system under low carbon economy [J].Accounting research, 2010,15:56-59.

[7]Biming Liang,Wenchun Jiang. Construction of production enterprise integrated performance evaluation under low carbon economy [J].Friends of accounting, 2011,12:32-34 